\title{
Analysis of Temperature Trends over Limpopo Province, South Africa
}

\author{
Milambo Freddy Tshiala (Corresponding author) \\ Centre for Environmental Studies and Department of Geography, Geoinformatics and Meteorology \\ University of Pretoria, Private Bag X20, Hatfield 0028, Pretoria, South Africa \\ Tel: 27-836-691-702Ｅ-mail: mftshiala@hotmail.com \\ Jane Mukarugwiza Olwoch \\ Centre for Environmental Studies and Department of Geography, Geoinformatics and Meteorology \\ University of Pretoria, Private Bag X20, Hatfield 0028, Pretoria, South Africa
}

Tel: 27-124-203-325Ｅ-mail: Jane.olwoch@up.ac.za

Francois Alwyn Engelbrecht

Council for Scientific and Industrial Research

Natural Resources \& the Environment-Atmospheric Modelling

Climate Studies, Modelling and Environmental Health, Pretoria 0001, South Africa

Tel: 27-128-412-911_E-mail: fengelbrecht@csir.co.za

Received: November 26, 2010 Accepted: December 14, 2010 doi:10.5539/jgg.v3n1p13

\begin{abstract}
Detailed analyses of trends in annual and seasonal minimum and maximum temperatures, as well as the diurnal temperature range, were investigated over Limpopo Province, South Africa, for the period 1950 to 1999 . Daily data from 30 catchments were used to analyze the trends. Overall there was an increase of $0.12^{\circ} \mathrm{C}$ per decade in the mean annual temperature for the 30 catchments, over the 50 year period. A non-uniform pattern of changes in temperature was evident across the different catchments; $13 \%$ of the catchments showed negative trends while $87 \%$ showed positive trends in their annual mean temperature. Furthermore, $20 \%$ of catchments showed negative trends while $80 \%$ of catchments showed positive trends in their diurnal temperature range. The seasonal trends showed variability in mean temperature increase, of about $0.18^{\circ} \mathrm{C}$ per decade in winter and $0.09^{\circ} \mathrm{C}$ per decade in summer. The significance of this work lies in the linkage of temperature to the hydrological cycle.
\end{abstract}

Keywords: Annual temperature trends, Seasonal temperature trends, Diurnal range trend, Limpopo, South Africa, Hydrology

\section{Introduction}

Several studies investigating temperature trends over South Africa have been published in the literature. Muhlenbruch (1992) reported a decrease in maximum temperatures but an increase in minimum temperatures in South Africa between 1940 and 1989. This pattern was most pronounced during the spring season from September to November (SON), but reversed in the autumn period of March to May (MAM). These findings were later contrasted by Karl et al. (1993) who reported an increase in both maximum temperatures and minimum temperatures but a decrease in the diurnal temperature range in South Africa, for the period 1951 to1991. Jones (1994) reported consecutive cooling and warming periods for 1885 to 1915 and 1915 to 1945 , respectively. The paper also reported a slight cooling period from 1945 to 1970 , followed by a rapid warming period from 1970 to 1990 . Hugues and Balling (1995) reported an increase of $0.11^{\circ} \mathrm{C}$ in maximum and $0.12^{\circ} \mathrm{C}$ in average temperatures per decade, over the period 1960 to 1990 . These trends were significant for both non-urban and urban stations. 
Kruger and Shongwe (2004) have shown that the average temperatures in South Africa for the 1990s was significantly warmer than preceding decades, $18.48^{\circ} \mathrm{C}$ for 1991 to 2003 compared to $18.18^{\circ} \mathrm{C}$ for 1960 to 1990 . The average temperature trend from 1991 to 2003 was $0.09^{\circ} \mathrm{C}$ per decade, compared with $0.11^{\circ} \mathrm{C}$ per decade from 1960 to 1990. It was also found that there was a relatively rapid increase in average temperatures in the early 1960s, which consequently caused the general increase in temperature over the full period from 1960 to 1990. While the trend in annual mean temperatures of $0.13^{\circ} \mathrm{C}$ per decade for 1960 to 2003 is significant, insignificant trends of $0.04^{\circ} \mathrm{C}$ per decade and $0.01^{\circ} \mathrm{C}$ per decade were found for 1960 to 1982 and 1983 to 2003 , respectively.

In particular, Kruger and Shongue (2004) found significant increase in temperature between 1960 and 2003 for the three stations Bela Bela, Polokwane and Musina situated in the Limpopo Province in north-eastern South Africa. This paper aims to provide a spatially more continuous picture of temperature trends over Limpopo, by considering trends in temperature for all catchments within the province. Furthermore, the results on temperature trends from the different studies reported on above do not provide a consistent picture of temperature trends over South Africa and Limpopo in particular.

The present study will attempt to obtain more clarity on the sign and pattern of the temperature signal over Limpopo.

South Africa is known to be a water stressed country (Schulze, 2000 and 2001; RSA, 2002; IWMI, 1996; Ochieng and Otieno, 2004). Temperature changes influence the hydrological cycle processes in a direct or indirect ways (Parry et al., 2001). An increase in temperature typically causes the intensification of the hydrological cycle, as a result of the increase in evaporation as well as precipitation. That is, temperature changes may lead to changing patterns of precipitation, the spatial and temporal distribution of runoff, soil moisture, and groundwater reserves, as well as (increase) in the frequency of occurrence of droughts and floods (Arora et al., 2005). Indeed, Parry et al., (2001) reported a steep rise in the water shortage curve when plotted against rise in temperature. (Schulze, 2000 and 2001) reported that South Africa is situated in a region with increasing levels of water quality problems, amalgams of population growth and issues of social and economic development. Further stresses on water resources arising from potential climate change will intensify these problems over much of the country and the wider Southern African region.

Changing temperature patterns could also have knock-on effects on soil characteristics, since temperature and water content are important soil physical factors for plant growth. Non-optimum levels of water and temperature conditions can strongly perturb plant development, especially at the early stages of growth such as seed germination and emergence (Helms et al., 1996). Identification of temperature and rainfall trends over Limpopo is necessary in order for knockon effects on aspects such as soil and plant growth characteristics to be explored.

This paper aims to determine trends in the monthly, seasonal and annual, maximum and minimum temperatures, as well as the diurnal temperature range over Limpopo-from daily temperature records over a period covering 5 decades. Results from this analysis can be used as a base to investigate the impacts of temperature on agriculture and water. Results from the analyses will also add more knowledge on past climatic variability and provides a platform for understanding the regional impacts of global warming and climate change.

\section{Regional setting}

This study focuses on Limpopo Province located in the north of South Africa (approximately $22-25^{\circ} \mathrm{S}, 27-32^{\circ} \mathrm{E}$ ). Limpopo is one of the developing provinces in South Africa and is particularly vulnerable to climate change impacts, due to its exposure to extreme weather events (Levey and Jury, 1996; Tennant and Hewitson, 2002; Cook et al., 2004). The province has three distinct climatic regions: the Lowveld region which is characterised by a semi-arid climate(s), the Middle- and Highveld that is considered semi-arid, and Escarpment that experiences sub-humid climate (Limpopo Department of Agriculture, 2008).

The province experiences long sunny days and dry weather conditions on most days. During the summer months, warm days are often interrupted by a short-lived thunderstorm (Limpopo Department of Agriculture, 2008). It can get very hot in summer (October and March), with average temperatures rising to $27^{\circ} \mathrm{C}$ in summer and $20^{\circ} \mathrm{C}$ in winter. The bulk of the precipitation occurs in summer, and annual rainfall totals range from about 400-600 $\mathrm{mm}$ over most of the province (Anon, 2007). Although communities in the Limpopo region may have some ability to adapt to the long term changes in climate, such as increased seasonal temperature and changed patterns of precipitation, they are nevertheless heavily stressed by the frequency of occurrence of extreme weather events (defined as weather phenomena that are at the extremes of the historical distribution, especially severe or unseasonal weather-WMO, 2004.). The province has great biodiversity and is very important for tourism, because of the presence of a number of national parks such as the Kruger National Park/Limpopo Transfrontier 
Park. Furthermore, the province has a large rural population and farming is of considerable importance (Reason et al., 2005).

\section{Data and methodology}

Data used in the study was provided by the School of Bioresources Engineering and Environmental Hydrology at the University of KwaZulu-Natal. It consisted of daily maximum and minimum temperature from hydroclimatic data collected from more than 970 qualifying temperature stations, over the 50 year period 1950 to 1999. The data was quality controlled using infilling and record extension techniques developed by Schulze and

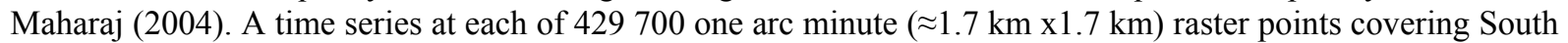
Africa was derived, using regionally and seasonally determined lapse rates and other physically appropriate spatial interpolation approaches. More details on this method can be obtained from Schulze and Maharaj (2004).

During the pre-processing stage, the daily average temperature (AvT) was calculated from the arithmetic averages of the daily maximum temperature (MxT) and minimum temperature (MnT). The diurnal temperature range (DTR) was computed by subtracting the daily MnT from the daily MxT. Monthly means were calculated from the daily average, minimum and maximum temperatures. Thereafter, temperature trends were calculated for the monthly averages over the fifty year period for each catchment. The trends were estimated by fitting a linear regression line on the monthly temperature data. This procedure for identifying trends is used widely (e.g. Arora et al., 2005; Mote, 2003) and has also been applied to identify trends at specific weather stations in South Africa (e.g. Kruger and Shongue, 2004).

The following linear trends function was applied to the seasonal/annual temperature values of the catchments:

$$
f(x, t)=a x(t)+b
$$

Where $\mathrm{t}$ (months) $=1,2, \ldots, 600 ; \mathrm{x}(\mathrm{t})$ is the seasonal/annual temperature ( e.g., average, maximum or minimum temperature) and a is the linear trend (in ${ }^{\circ} \mathrm{C} /$ year).

Furthermore, the annual and seasonal temperature averages were calculated for each of the catchments, and the corresponding trends were calculated. Seasons were defined following the usual conventions, e.g. winter: June to August (JJA) and summer: December to February (DJF).

In addition, the trends were tested for statistical significance using the Mann-Kendall test, which is a non-parametric test (Hall et al., 2006; Capodici et al., 2008). The $\mathrm{n}$ time series values $\left(\mathrm{X}_{1}, \mathrm{X}_{2}, \mathrm{X}_{3}, \ldots, \mathrm{X}_{\mathrm{n}}\right)$ are replaced by their relative ranks $\left(R_{1}, R_{2}, R_{3}, \ldots R_{n}\right)$ (Starting at 1 for the lowest up to $n$ ).

The Mann-Kendall statistic $\mathrm{S}$ is:

$$
S=\sum_{i=1}^{n-1}\left[\sum_{j=i+1}^{n} \operatorname{sgn}\left(R_{i}-R_{j}\right)\right]
$$

Where;

$$
\operatorname{sgn}(x)= \begin{cases}1 & \forall x>0 \\ 0 & \forall x=0 \\ -1 & \forall x<0\end{cases}
$$

If the null hypothesis $\mathrm{H}_{0}$ is true, the $\mathrm{S}$ is approximately normally distributed with;

$$
\begin{aligned}
\mu & =0 \\
\sigma & =\frac{n(n-1)(2 n+5)}{18}
\end{aligned}
$$

The z-statistic is therefore

\section{Results and discussion}

$$
z=\frac{|S|}{\sigma^{0.5}}
$$

\subsection{Mean monthly temperature over Limpopo}

Analysis of the mean monthly temperature over Limpopo province is depicted in Figure 1. October to March are the months displaying the highest temperatures. Temperatures peak in December and January at about $25^{\circ} \mathrm{C}$. The 
lowest temperatures occur in July (about $15^{\circ} \mathrm{C}$ ), with the average annual temperature being about $22^{\circ} \mathrm{C}$. The graph simply shows the intra-annual cycle in temperature that is driven by radiation.

\subsection{Trends in mean annual maximum, minimum and average temperature}

Figure 3 shows that the majority of the considered catchments (70\%) experienced positive trends in the annual mean maximum temperature (AMMxT), with $63 \%$ of the catchments displaying positive trends in the annual mean minimum temperature (AMMnT) (Figure 4). Furthermore, the analysis of average temperature (AvT) exhibited positive trends for $87 \%$ of the catchments (Figure 2). The generally positive temperature trends in Limpopo are consistent with the results of Kruger and Shongwe, 2004.

Detailed analysis of mean annual average temperatures show that the highest positive mean annual trend recorded among the 30 catchments over Limpopo was $0.1^{\circ} \mathrm{C}$ per decade, whilst the largest negative trend is $-0.03^{\circ} \mathrm{C}$ per decade. Not all the areas in Limpopo exhibited the same trends, with the north western portions warming up the fastest. The general rising trends in temperature could have implications for evaporation and water management in the province.

Trends averaged over all the catchments were investigated using the Mann-Kendall test as described earlier. The trends in the mean annual maximum, minimum and mean temperature were all found to be statistically significant at 0.01 significance level. For all cases, the trends averaged over the catchments were found to be positive. Figure 2 shows that the majority of the considered catchments $((70 \%))(87 \%)$ experienced positive trends in the annual mean maximum temperature (AvT).

Figure 3. The analysis of AMMxT (Figure 3) shows that different catchments experienced varying maximum temperature trends, with the north-western parts warming up the fastest. The present results corroborates those of Kruger and Shongwe (2004), who demonstrated that there weresignificant temperature increases between 1960 and 2003, based on the data from three Limpopo stations they have considered. From the results of Kruger and Shongwe, Limpopo in general experienced a positive trend in temperature, of $0.1^{\circ} \mathrm{C} /$ decade for the period 1960-2003. These results are consistent with those found in this analysis, which is showing the trend of $0.1{ }^{\circ} \mathrm{C}$ per decade during the period of 1950-1999 for catchments in the northwest.

Figure 4 shows that the trends in the mean annual minimum temperatures over the period 1950 to 1999 in Limpopo province. The strongest trends have occurred over the northwestern part of the province, the trends in minimum temperatures are in general weaker than the maximum temperature trends.

\subsection{Seasonal trends}

As illustrated in Figure 5 seasonal (winter and summer) temperature trends exhibit variations over different catchments and seasons. Both seasons experienced generally positive trends in temperature over the last 50 years. The mean annual temperature trends of the thirty catchments were found to be $0.18^{\circ} \mathrm{C} /$ decade and $0.09^{\circ} \mathrm{C} / \mathrm{decade}$ for winter and summer, respectively. In winter the majority of catchments, $\sim 87 \%$ /decade (See Figure 5), experienced positive trends, while $13 \%$ of the catchments showed negative trends. Summer temperature trends (Figure 5) followed a similar pattern than the winter pattern. These results indicate that temperature trends over the 50 years from 1950-1999 are not consistent between seasons. Trends were investigated using the Mann-Kendall test as described earlier and the results indicated that the trends in summer temperatures were significant at the 0.05 significance level. For the winter period as well, the trends were found to be significant at the 0.01 level.

Figures 5 Seasonal temperature trends for the period 1950-1999 exhibit variations over different catchments and seasons.

\subsection{Trends in diurnal temperature range (DRT)}

In the present paper, we define the DRT as the temperature difference between the maximum and minimum temperature over a period of twenty four hours, starting from $00 \mathrm{~h} 00$ (at mid-night). In a careful analysis of temperature trends for a period of 50 years (starting from 1950); it was found that about $80 \%$ of the catchments showed positive trends, with $20 \%$ showed negative trends in the DTR (Figure 6). At the regional scale, variation in DTR trends may be caused different local factors such as soil moisture; by influencing evaporative cooling, the ground albedo and the ground heat capacity. These effects tend to be most influential in the occurrence of extreme hot days as reported by Durre et al. (2000). Catchments found in the Northern central interior of Limpopo Province experienced the highest increases in the DTR, in association with large increase in maximum (see Figure 6).

As has been reported widely in the literatures, the observed global average positive temperature trend over land has been linked to a large increase in the Tmin (see for example, Karl et al., 1993; Easterling et al., 1997; Jin and 
Dickinson 2002). The increase in Tmax has been observed to be at a much smaller rate, resulting in a decreasing trend in DTR, this magnitude of which is comparable to the mean warming itself. As an identifiable characteristic of recent climate change, this trend is important in diagnosing the forcing responsible for the change, and in particular the anthropogenic component. However, the cause of the DTR trend is still poorly understood, as is its relation to anthropogenic forcing. The higher albedo of clouds decreases the downward solar radiation during the day, and thereby reduces Tmax. Indeed, observational studies link the decreasing DTR to coincident increases in precipitating clouds (Karl et al., 1993). These low base clouds are particularly effective in reflecting sunlight, and changes in their frequency of occurrence would be expected to have the strongest impact on the DTR. Clouds also produce more downward long-wave radiation, so increasing night time cloud cover which would increase Tmin and thereby decrease the DTR. However, the tendency of the diurnal cycle of cloud cover over global land areas during recent years is currently unknown.

\section{Discussion and conclusions}

The global average surface temperature has increased by $0.6 \pm 0.2^{\circ} \mathrm{C}$ over the last century, and it is expected that by 2100 the increase in temperature could range between 1.4 to $5.8^{\circ} \mathrm{C}$ (IPCC, 2007). Temperature changes have not been uniform globally, but have varied over regions and different parts of the lower atmosphere. In the South African context, a rise in temperature has been reported by (Hughes and Balling, 1999; Kruger and Shongue, 2004). This study departs from others performed over South Africa in the sense that more spatial detail of temperature trends is provided, and it therefore adds a significant contribution to our understanding of possible effects of temperature changes over Limpopo Province. Overall there was an increase of $0.12^{\circ} \mathrm{C} / \mathrm{decade}$ in the mean annual temperature for the 30 catchments over the 50 year period. A non-uniform pattern of changes in temperature were evident across the different catchments. The long term fluctuation in temperature has been represented by computing the linear trends in the data records. Although, the variability of temperature trends exhibits a spatial dependence, the trends are undoubtedly real and the warming is large enough to have significant impacts on the hydrology and ecosystems of the region.

In our analysis of trends of DTR over Limpopo, it was also observed that the variations in the local temperature trends are not spatially uniform. Each catchment exhibits unique trends; for instance, positive DTR trends seem to occur more in the northern and central regions of the province. This result provide additional and specific information that corroborate with the general increase in temperature over Limpopo reported by Kruger and Shongwe (2004) who is findings were based on a small number of stations in the province. Trends in seasonal temperatures showed that the temperature trends are not uniform throughout the year (see Figure 5), with winter being the season with highest temperature trends on average and spring being the season with lowest trends. In general, there is no spatial coherence in the results of temperature trends for specific seasons. The mean maximum, minimum and average annual temperatures show positive trends for the majority of the catchments. From these findings, the rising temperature patterns provide favourable conditions for the geographical expansion of vector borne diseases such as malaria, East coast fever - especially if the temperature increases would occur in conjunction with increases in extreme rainfall events. The assertion is derived from the several mathematical models as well as surveillance and direct observations reported in the literature (see for example (in) Olwoch et al., 2008). In addition, climate impacts on human health will interact with those on rural livelihoods, in particular (Midgley et al., 2007).

The potential contribution of these findings to studies of livelihoods in Limpopo is illustrated by the findings reported by FAO (2004), who used temperature changes as proxies to estimate that Southern Africa households were more susceptible to climate variability and drought; that these households were increasingly being threatened by desertification processes, degradation of land and water resources and loss of biodiversity. This study provides clear evidence of rising temperatures over Limpopo, and potential links to the hydrological cycle and impacts on agriculture and water resources in the province need to be explored in future research.

\section{Acknowledgement}

The authors acknowledge the School of Bioresources Engineering and Environmental Hydrology at the University of KwaZulu-Natal for the provision of the weather data. The Water Research Commission (WRC), Canon Collins Trust in Cape Town as well as the University of Pretoria are gratefully acknowledged for financial assistance of the first author.

\section{References}

Anon. (2007). Pietersburg: The Columbia Encyclopaedia, 6th edition 2007. Columbia University Press. [Online] Available: www.encyclopedia.com (April 4, 2008) 
Arora, M., Goel, N. K \& Singh, P. (2005). Evaluation of temperature trends over India. Hydrological Sciences-Journal-des Sciences Hydrologiques, 50(1).

Bolin, B., Doos, B. R., Jager, J., \& Warrick, R. A. (1986). The greenhouse effect, climatic change and ecosystems. Chichester: J. Willer, pp. 206-311.

Burn, D. H., \& Elmur, M. A. H. (2002). Detection of hydrologic trends and variability. Journal of hydrology, 255, 107-122. doi:10.1016/S0022-1694(01)00514-5, http://dx.doi.org/10.1016/S0022-1694(01)00514-5

Capodici, F., Ciraolo, G., La loggia, G., Luzzo, L., Noto, L. V., \& Noto, M. T. (2008). Time series analysis of climate and vegetation variables in the Oreto Watershed (Sicily, Italy). European Water, 23/24, 133-145.

Cook, C., Reason, C. J. C., \& Hewitson, B. C. (2004). Wet and dry spells within particularly wet and dry summers in the South African summer rainfall region. Climate Research, 26, 17-31. doi:10.3354/cr026017, http://dx.doi.org/10.3354/cr026017

Davis, R. E., Knappenberger, P. C., Michaels, P. J., \& Novicoff, W. M. (2003). Changing heat-related mortality in the United States. Environmental health perspectives, 111, 1712-1718. doi:10.1289/ehp.6336, http://dx.doi.org/10.1289/ehp.6336

Easterling, D. R., Horton, B., Jones, P. D., Peterson, T. C., Karl, T. R., Parker, D. E., Salinger, M. J, Razuvayev, V., Plummer, N, Jamason, P., Folland. C. K. (1997). Maximum and Minimum Temperature Trends for the Globe. Science, 277(5324), 364-367. doi:10.1126/science.277.5324.364, http://dx.doi.org/10.1126/science.277.5324.364

Food \& Agricultural Organization (FAO) (2004). Drought impact mitigation and prevention in the Limpopo River basin. A situation analysis. Land and water discussion paper 4. [Online] Availabile: www.sarpn.org.za/documents/d0001237/p1367-limpopo-2004_cover.pdf (February 22, 2010).

Gallo, P., Rovere, M., \& Spohr, E. (1999). Supercooled confined water and the mode coupling crossover temperature. Physical Review Letters, 85, 4317-4320. doi:10.1103/PhysRevLett.85.4317, http://dx.doi.org/10.1103/PhysRevLett.85.4317

Hall, A. W., Alexander, W., Whitfield, P. H., \& Cannon, A. J. (2006). Recent variations in temperature, precipitation and streamflow in the Rio Grande and Pecos River Basins of New Mexico and Colorado. Reviews in fisheries science, 14(1), 51-78. doi:10.1080/10641260500340835, http://dx.doi.org/10.1080/10641260500340835

Helms, T. C., Deckard, E., Goos, R. J., \& Enz, J. W. (1996). Soil moisture, temperature and drying influence on soybean emergence. Agricultural Journal, 88, 662-667.

Hugues, S. H., \& Balling, R. C. (1996). Urban influences on South African temperature trends. International Journal of Climatology, $\quad 16, \quad 935-940$. doi:10.1002/(SICI)1097-0088(199608)16:8<935::AID-JOC64>3.0.CO;2-V, http://dx.doi.org/10.1002/(SICI)1097-0088(199608)16:8<935::AID-JOC64>3.0.CO;2-V

Intergovernmental Panel on Climate Change (IPCC). (2007). Climate change 2007- the physical science basis. Contribution of working group I to the fourth assessment report of the Intergovernmental Panel on Climate Change. Cambridge University Press, Cambridge, United Kingdom and New York. USA.

International Water Management Institute (IWMI). (1996). World Water Demand and Supply, 1990 to 2025: Scenarios and Issues, Research Report19.

Jin, M., \& Dickinson, R. E. (2002). New Observational Evidence for Global Warming from Satellite Data Set. Geophys. Geophys. Res. Lett., 29(10), 10.1029/2001GL013833. doi:10.1029/2001GL013833, http://dx.doi.org/10.1029/2001GL013833

Jones, P. D. (1994). Hemispheric surface air temperature variations: A reanalysis and an update to 1993. Journal of Climate, 7, 1794. doi:10.1175/1520-0442(1994)007<1794:HSATVA>2.0.CO;2, http://dx.doi.org/10.1175/1520-0442(1994)007<1794:HSATVA>2.0.CO;2

Karl, T. R., Jones, P. D., Knight, R. W., Kukla, G., Plummer, N., Razuvayev, V., Gallo, K. P., Lindseay, J., Charlson, J. R., \& Peterson, T. C. (1993). Asymmetric trends of daily maximum and minimum temperature. $\begin{array}{lllll}\text { Bulletin American } & \text { Meteorologycal } & \text { Society, } & 74, & 1007 .\end{array}$ doi:10.1175/1520-0477(1993)074<1007:ANPORG>2.0.CO;2, http://dx.doi.org/10.1175/1520-0477(1993)074<1007:ANPORG $>2.0 . C O ; 2$

Kruger, A. C., \& Shongwe, S. (2004). Temperature trends in South Africa: 1960-2003. South Africa. International journal of climatology, 24, 1929-1945. doi:10.1002/joc.1096, http://dx.doi.org/10.1002/joc.1096 
Levey, K. E., \& Jury, M. R. (1996) .Composite intra-seasonal oscillations of convection over Southern Africa. Journal of Climate, 9, 1910-1920. doi:10.1175/1520-0442(1996)009<1910:CIOOCO >2.0.CO;2, http://dx.doi.org/10.1175/1520-0442(1996)009<1910:CIOOCO >2.0.CO;2

Limpopo Department of Agriculture (2008). Background. [Online] Available: http://www.lda.gov.za/index.php?option=com_content\&view=article\&id=60\&Itemid=55 (April 4, 2008).

Mendelsohn, R., Dinar, A. \& Dalfelt, A. (2000). Climate change impacts on African agriculture. Preliminary analysis prepared for the World Bank, Washington, District of Columbia, pp 25.

Mitosek, H. T. (1992). Occurrence of climate variability and change within the hydrologic time series: a statistical approach. Report CP-92-05, International Institute for Applied Systems Analysis, Laxemburg, Austria. Midgley, M, Chapman, R., Mukheibir, P., Tadross, M., Hewitson, B., Wand, S., Schulze, R., Lumsden, T., Horan, M., Waburton, M., Kgope, B., Mantlana, B., Knowles, B., Abayomi, A., Ziervogel, G., Cullis, R., \& Theron, A. (2007). Impacts, vulnerability and adaptation in key South African sectors. Long-Term Mitigation Scenarios in put report 5 (LTMS).Department of Environmental Affairs and Tourism of South Africa, pp 20.

Mote, P. W. (2003). Trends in temperature and precipitation in the pacific Northwest during the Twentieth century. University of Washington. Washington. North West Science, 77(4), 271-282.

Muhlenbrunch-Tegen, A. (1992). Long-term surface temperature variations in South Africa. Climatology Research Group, University of the Witwatersrand. South African Journal of Science, 88, 197-205.

Ochieng, G. M. M., \& Otieno, F. (2004). Water management tools as a means of averting a possible water scarcity in South Africa by the year 2025. Water SA, 30, 5. [Online] Available: http://www.wrc.org.za (February 18, 2010).

Olwoch, J. M., Reyers, B., Engelbrecht, F. A., \& Erasmus, B. F. N. (2008). Climate change and the tick-borne disease, Theileriosis (East Coast fever) in Sub-Saharan Africa. Journal of Arid Environments, 72(2), 108-120. doi:10.1016/j.jaridenv.2007.04.003, http://dx.doi.org/10.1016/j.jaridenv.2007.04.003

Parry, M., Arnell, N., McMichael, I. T., Nicholls, R., Martens, P., Kovats, S., Livermore, M., Rosenzweig, C., Iglesias, A., \& Fischer, G. (2001). Millions at risk: defining critical climate change threats and targets. Global Environmental Change, 11, 181-183. doi:10.1016/S0959-3780(01)00011-5, http://dx.doi.org/10.1016/S0959-3780(01)00011-5

Reason, C. J. C., Hachigonta, S., \& Phaladi, R. F. (2005). Interannual variability in rainy season characteristics over the Limpopo region of Southern Africa. South Africa. International Journal of Climatology, 25, 1835-1853. doi:10.1002/joc.1228, http://dx.doi.org/10.1002/joc.1228

Reilly, J. (1996). Agriculture in a changing climate: Impacts and Adaptation, in Watson, R. T., Zinyowera, M. C., Moss, R. H., and Dokken, D. J. (eds), ClimateChange, 1995. Impacts, Adaptations and Mitigation of Climate Change: Scientific-Technical Analyses, Cambridge University Press, Cambridge, U.K., pp 427-467.

Republic of Africa. (2002). Proposed First Edition National Water Resource Strategy.

Schulze, Meigh, J. \& Horan, M. (2001). Present and potential future vulnerability of eastern and southern Africa's hydrology and water resources. South African Journal of Science, 97, 150-160.

Schulze, R. E. (2000). Modelling hydrological responses to land use and climate change: a southern African perspective. Ambio, 29, 12-22.

Schulze, R. E., \& Maharaj, M. (2004). Development of a database of gridded daily temperatures for Southern Africa. Water Research Commission. WRC Report No. 1156/2/04. Pretoria, South Africa.

Tennant, W. J. \& Hewitson, B. (2002). Intra-seasonal rainfall characteristics and their importance to the seasonal prediction problem. International Journal of Climatology, 22, 1033-1048. doi:10.1002/joc.778, http://dx.doi.org/10.1002/joc.778

World Meteorological Organization (WMO). (2004). Workshop on Severe and Extreme Events Forecasting. Toulouse. 


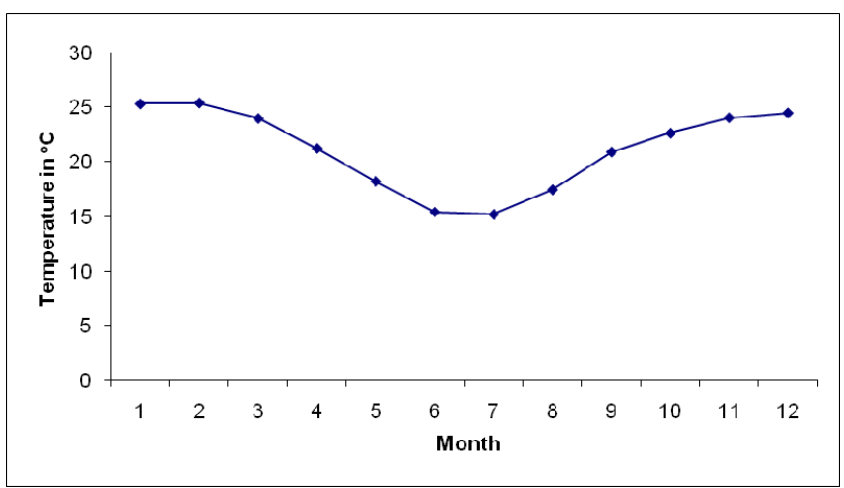

Figure 1. Monthly mean temperature in Degree Celsius $\left({ }^{\circ} \mathrm{C}\right)$ from 1950 to 1999 over Limpopo province

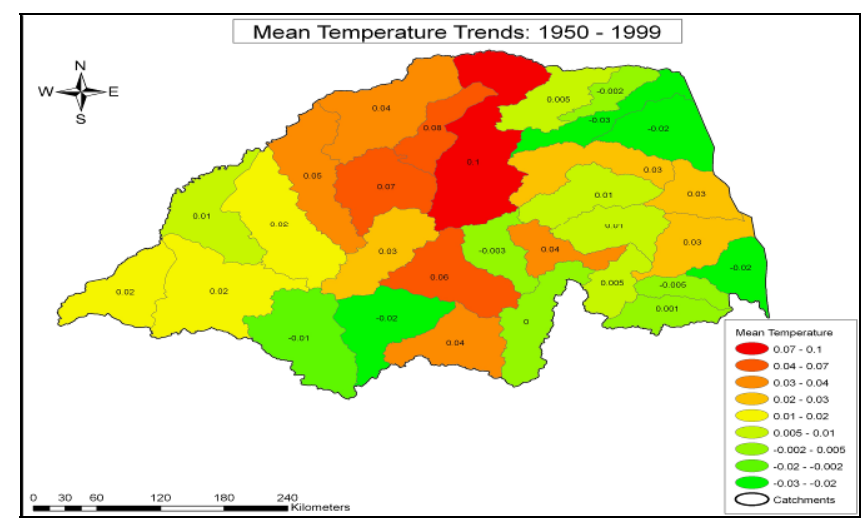

Figure 2. Trend $\left({ }^{\circ} \mathrm{C} /\right.$ decade $)$ in mean annual temperature for the period 1950-1999

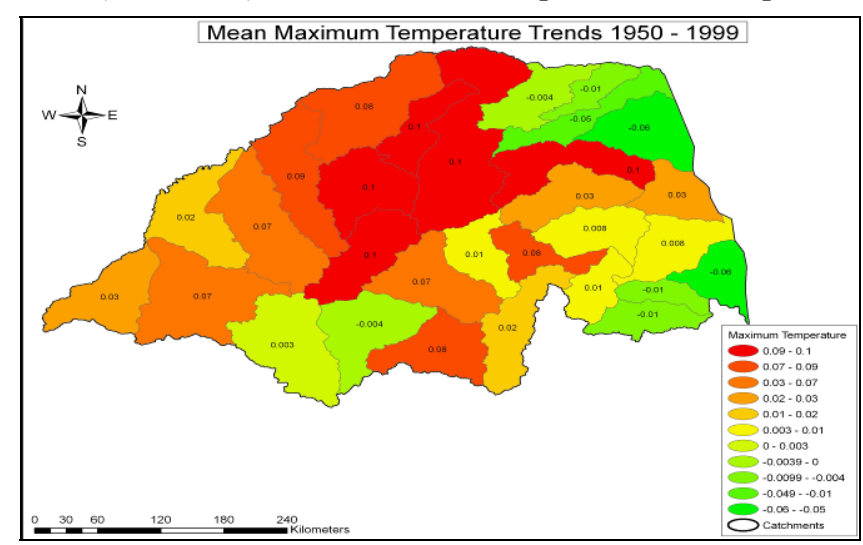

Figure 3. Trend $\left({ }^{\circ} \mathrm{C} / \mathrm{decade}\right)$ in mean maximum annual temperature for the period 1950-1999

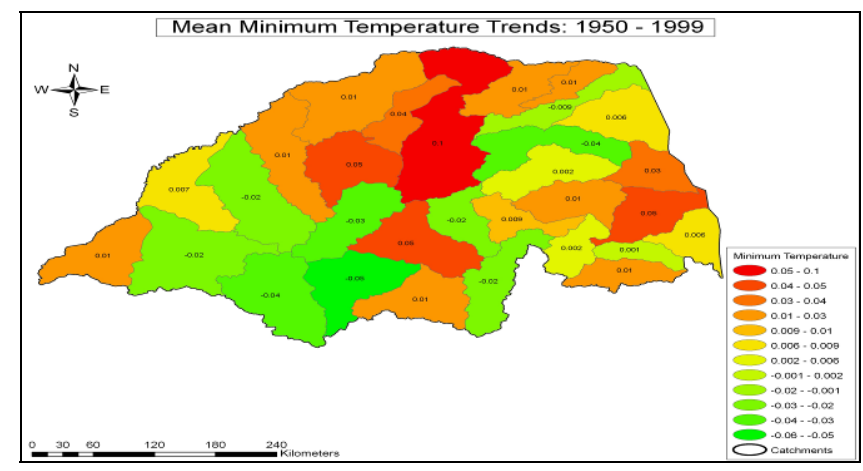

Figure 4. Trend $\left({ }^{\circ} \mathrm{C} /\right.$ decade $)$ in mean minimum annual temperature for the period 1950-1999 


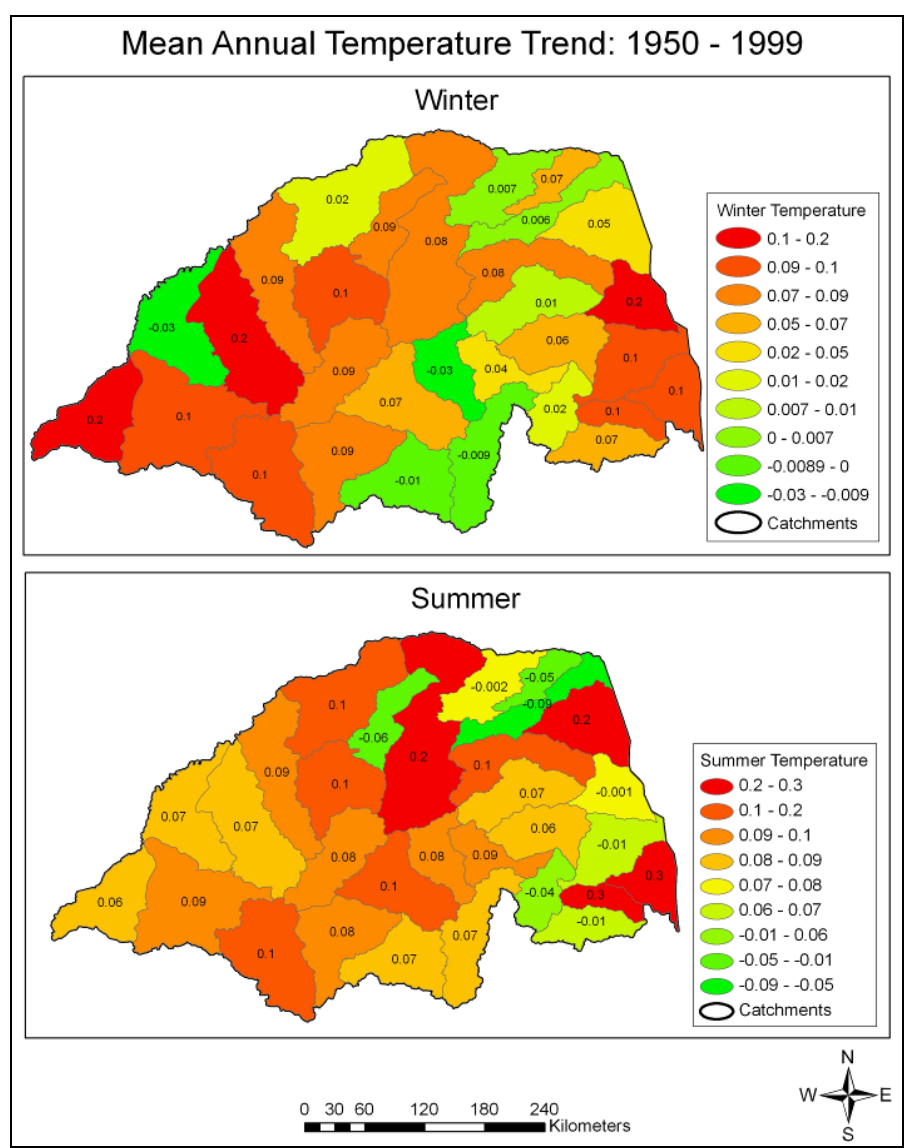

Figure 5. Trend ( ${ }^{\circ} \mathrm{C} /$ decade) in mean winter and summer annual temperature for the period 1950-1999

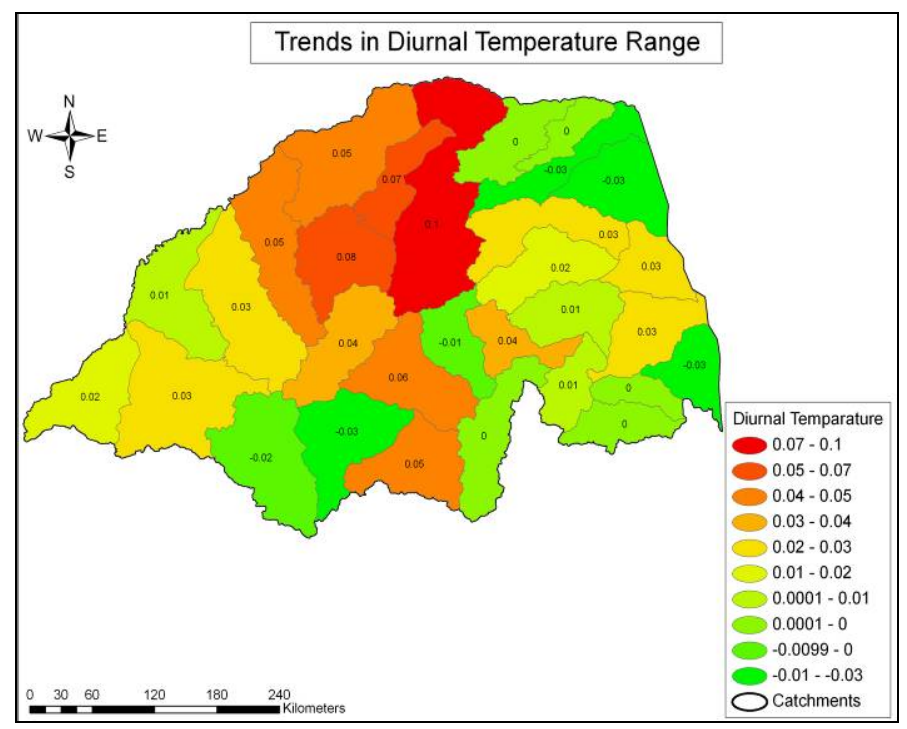

Figure 6. Trends in diurnal temperature range $\left({ }^{\circ} \mathrm{C} / \mathrm{decade}\right)$ for the period $1950-1999$ 